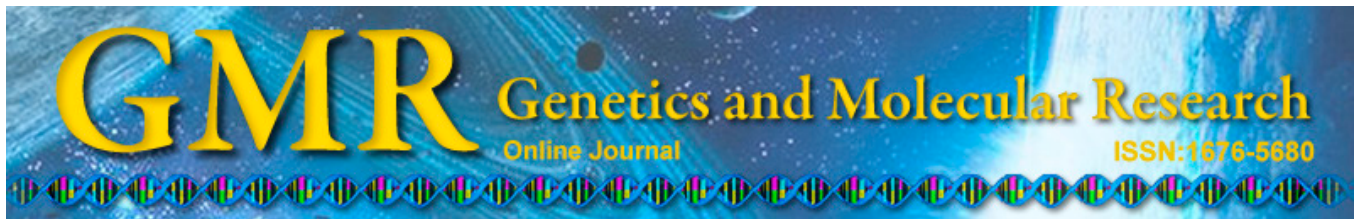

\title{
Development and characterization of microsatellite markers for molecular genetic diversity in Atrina pectinata
}

\author{
Y.F. Ning ${ }^{1,2}$, Z.B. Li ${ }^{1,2}$, J.B. Shangguan ${ }^{1,2}$, Y.S. Huang ${ }^{1,2}$, P.D. Jiang ${ }^{1,2}$, \\ A.L. Xu ${ }^{1,2}$ and Y. Yuan ${ }^{1,2}$ \\ ${ }^{1}$ Fisheries College, Jimei University, Xiamen, China \\ ${ }^{2}$ Fujian Provincial Key Laboratory of Marine Fishery \\ Resources and Eco-Environment, Xiamen, China \\ Corresponding author: Z.B. Li \\ E-mail: lizhongbao@jmu.edu.cn
}

Genet. Mol. Res. 14 (3): 8290-8293 (2015)

Received October 1, 2014

Accepted April 7, 2015

Published July 27, 2015

DOI http://dx.doi.org/10.4238/2015.July.27.17

\begin{abstract}
The pen shell, Atrina pectinata, is an economically valuable species that is widely distributed along the coastal waters of temperate and tropical areas, mainly growing in the Indian and Pacific Oceans. Eight novel microsatellite loci from the genome of A. pectinata were developed using fast isolation by amplified fragment length polymorphism of sequence containing repeats. The loci were screened in 30 wild individuals. The results showed that the number of alleles per locus and the polymorphism information content ranged from 2-6 and from $0.233-0.447$, respectively. Observed and expected heterozygosities varied from 0.2069-0.7931 and 0.1887-0.5124, respectively. No significant deviations from HardyWeinberg equilibrium were detected. These microsatellite loci will be useful for further population studies of genetic diversity, population structure assessment, and conservation of $A$. pectinata.
\end{abstract}

Key words: Atrina pectinata; Genetic markers; Microsatellite; Fragment length polymorphism; Sequence containing repeats 


\section{INTRODUCTION}

The pen shell Atrina pectinata belongs to the order Mytiloida, family Pinnidae, which is widely distributed along the coastal waters of temperate and tropical zones in China and mainly grows in southeastern coastal provinces such as Fujian and Guangdong (Suck An et al., 2011). A. pectinata is a bivalve animal with high economic value for its rich nutrition and good taste (Fu et al., 2010). However, the natural resource of $A$. pectinata has sharply decreased because of overexploitation and worsening habitat conditions in recent decades (Ren and Yang, 2005). Currently, studies of the population structure of this economically valuable species remain insufficient and are limited for use in genetic resource conservation. Thus, studies on the development of genetic markers in A. pectinata are urgently needed.

Because they are non-coding, highly polymorphic, co-dominant genetic markers, microsatellites are efficient tools for researching population genetics $(\mathrm{Li}, 2006)$. In this study, a novel marker suite of 8 loci in A. pectinata was developed, which may be useful for further studies of the population genetics and the protection of species resources.

\section{MATERIAL AND METHODS}

The microsatellite-enriched library was developed from a single $A$. pectinata using fast isolation by amplified fragment length polymorphism of sequences containing repeats (Zane et al., 2002). Thirty individuals of $A$. pectinata were collected from Hainan, China, and were assayed for the 8 microsatellite markers. Genomic DNA was extracted from muscle tissues using a Genomic DNA Extraction kit (Tiangen, Beijing, China), followed by $1 \%$ agarose gel electrophoresis and ultraviolet spectrophotometry. Samples were digested with restriction enzyme FastDigestTru1I by incubation for $10 \mathrm{~min}$ at $65^{\circ} \mathrm{C}$. The $\mathrm{MseI}$ adapter 1 (5'-ACGATGAGTCCTGAG-3') and MseI adapter 2 (5'-TACTCAGGACTCAT-3') were then ligated to the digestion fragments using T4 DNA ligase (Fermentas, Vilnius, Lithuania) overnight at $22^{\circ} \mathrm{C}$. The linker-ligated mixture was denatured at $95^{\circ} \mathrm{C}$ for $10 \mathrm{~min}$ and hybridized to the biotin-labeled oligonucleotide probes $(\mathrm{CT})_{15}$ and $(\mathrm{GT})_{15}$, then captured using Streptavidin-coated Magnetic Sphere Particles (Promega, Madison, WI, USA), with washing away of the nonannealed DNA. The recovered DNA fragments were amplified using MseI adapter 1 . After purification using GenCleanPCR (Generay, Shanghai, China), the products were ligated into the PMD19-T vector (Takara, Shiga, Japan) at $16^{\circ} \mathrm{C}$ for $8 \mathrm{~h}$ and transformed into Escherichia coli cells (Invitrogen, Carlsbad, CA, USA). The transformants were cultured on Luria-Bertani agar plates supplemented with $60 \mu \mathrm{g} / \mathrm{mL}$ ampicillin.

A total of 128 positive clones were amplified via colony-polymerase chain reaction with universal M13 primers. Sixty positive clones with DNA fragments above $500 \mathrm{bp}$ were sequenced by Invitrogen, and 25 pairs of primers were designed using Primer Premier version 5.0 (Clarke and Gorley, 2001). The amplification conditions for the 20 pairs of primers were successfully selected by optimization in an Eppendorf Mastercycler Gradient System (Eppendorf, Hamburg, Germany). Genomic DNA samples extracted from 30 wild individuals of A. pectinata from Hainan, China, were assayed for polymorphisms. The polymerase chain reaction was performed in a $10-\mu \mathrm{L}$ volume containing $50 \mathrm{ng}$ genomic DNA, 10X Taq buffer, 2 $\mathrm{mM} \mathrm{MgCl} 2,0.4 \mu \mathrm{M}$ of each primer, $0.2 \mathrm{mM}$ of each dNTP, and $0.25 \mathrm{U}$ Taq DNA polymerase (Fermentas). The reaction protocol was as follows: pre-denaturation at $94^{\circ} \mathrm{C}$ for $5 \mathrm{~min}$, fol- 
lowed by 37 cycles of denaturation at $94^{\circ} \mathrm{C}$ for $40 \mathrm{~s}$, annealing at an optimal temperature (Table 1) for $40 \mathrm{~s}$, and $72^{\circ} \mathrm{C}$ for $1 \mathrm{~min}$, with a final 10 -min elongation step at $72^{\circ} \mathrm{C}$. Amplified products were separated by electrophoresis in a Sequi-Gen Sequencing Cell (Bio-Rad, Hercules, CA, USA) and visualized by silver staining. The data matrix was analyzed to estimate the observed heterozygosity, expected heterozygosity, number of alleles, and the polymorphic information content using the POPGEN 32 (version 1.32) (Yeh et al., 2000) and CERVUS 3.0 (version 3.0) softwares.

\section{RESULTS AND DISCUSSION}

Eight loci were successfully developed from the $30 \mathrm{~A}$. pectinata individuals assayed. The loci were polymorphic, with the number of alleles ranging from 2-6 and polymorphism information content ranging from 0.233-0.447 (Table 1). Observed and expected heterozygosities ranged from $0.2069-0.7931$ and from $0.1887-0.5124$, respectively.

\begin{tabular}{|c|c|c|c|c|c|c|c|c|c|c|}
\hline $\begin{array}{l}\text { GenBank } \\
\text { accession No. }\end{array}$ & Locus ID & Primer sequences $\left(5^{\prime}-3^{\prime}\right)$ & Repeat motif & $\begin{array}{c}\mathrm{Ta} \\
\left({ }^{\circ} \mathrm{C}\right)\end{array}$ & $N_{\mathrm{A}}$ & PIC & $H_{\mathrm{O}}$ & $H_{\mathrm{E}}$ & P-HWE & $\begin{array}{c}\text { Allele } \\
\text { size (bp) }\end{array}$ \\
\hline KM588371 & ZJY1-2 & $\begin{array}{l}\text { F: ATTTGTATTAACGCCTCTGC } \\
\text { R: CCACCTACGGATGAACCT }\end{array}$ & $(\mathrm{CA})_{4} \mathrm{~N}(\mathrm{AT})_{4}$ & 55 & 3 & 0.371 & 0.5517 & 0.4301 & 0.2722 & $168-180$ \\
\hline KM588372 & ZJY1-14 & $\begin{array}{l}\text { F: AACTGGCAAAATAATGAG } \\
\text { R: AATGAAGGCAAAGTGTA }\end{array}$ & $(\mathrm{AG})_{38}$ & 45 & 2 & 0.439 & 0.2069 & 0.1887 & 0.5736 & $252-264$ \\
\hline KM588373 & ZJY1-21 & $\begin{array}{l}\text { F: AACTTGTGCAAGAATCG } \\
\text { R: CAGGGAATCTACAGGAA }\end{array}$ & $(\mathrm{AT})_{5}$ & 55 & 2 & 0.269 & 0.4138 & 0.3339 & 0.1815 & $145-150$ \\
\hline KM588374 & ZJY1-23 & $\begin{array}{l}\text { F: TCTACCCAATCAAAACACT } \\
\text { R: CGATAATGAATAAGAGCGT }\end{array}$ & $(\mathrm{AAAT})_{3}$ & 58 & 4 & 0.233 & 0.3103 & 0.2825 & 0.9905 & $200-220$ \\
\hline KM588375 & ZJY1-25 & $\begin{array}{l}\text { F: TTTCAAGCGTCTTTCCT } \\
\text { R: ATATCGACCAATTCCGT }\end{array}$ & $(\mathrm{CAA})_{3}$ & 53 & 3 & 0.407 & 0.7931 & 0.5124 & 0.0077 & $265-290$ \\
\hline KM588376 & ZJY1-29 & $\begin{array}{l}\text { F: ATCCCAAAGAGTAATAAACA } \\
\text { R: CAAAAGTTACTGGCTGAC }\end{array}$ & $(\mathrm{AG})_{12}$ & 50 & 6 & 0.447 & 0.5517 & 0.4882 & 0.9945 & 260-308 \\
\hline KM588377 & ZJY1-30 & $\begin{array}{l}\text { F: GTAAATGCCAAGAAACT } \\
\text { R: CCTTAAACTGCGATAA }\end{array}$ & $(\mathrm{AGG})_{3}$ & 57 & 4 & 0.300 & 0.3448 & 0.3079 & 0.9808 & 180-198 \\
\hline KM588378 & ZJY1-39 & $\begin{array}{l}\text { F: AGAAACTTTTGATGGATACTC } \\
\text { R: AAATAGCGTCATTCATTGT }\end{array}$ & $(\mathrm{AATT})_{3}$ & 60 & 2 & 0.371 & 0.5172 & 0.4991 & 0.8419 & $290-313$ \\
\hline
\end{tabular}

$\mathrm{Ta}=$ annealing temperature; $N_{\mathrm{A}}=$ number of polymorphic alleles per locus; PIC = polymorphism information content; $H_{\mathrm{O}}=$ observed heterozygosity; $H_{\mathrm{E}}=$ expected heterozygosity; $\mathrm{P}-\mathrm{HWE}=\mathrm{P}$ values for the Hardy-Weinberg equilibrium test (adjusted $\mathrm{P}=0.00625$ ).

No deviation from Hardy-Weinberg equilibrium in the population tested after Bonferroni's correction was observed (adjusted $\mathrm{P}=0.00625$ ). No loci showed significant linkage disequilibrium after Bonferroni's correction. Additional analysis using the MICRO-CHECKER software (van Oosterhout et al., 2004) showed no evidence for the presence of null alleles for any loci. The 8 novel polymorphic microsatellite loci presented may be useful for further population genetic studies of $A$. pectinata.

\section{ACKNOWLEDGMENTS}

Research supported by the Natural Science Foundation of Fujian Province (\#2014J01133), the National Natural Science Foundation of China (\#31272668), the Founda- 
tion for Innovative Research Team of Jimei University, China (\#2010A004), and the Program for New Century Excellent Talents in Fujian Province University [\#(2006)35].

\section{REFERENCES}

Clarke KR and Gorley RN (2001). PRIMER v5: user manual/tutorial. PRIMER-E Ltd., Plymouth.

Fu H, Wu Y, Gong Y, Jiang S, et al. (2010). Isolation and characterization of 15 polymorphic microsatellite markers for comb pen shell (Atrina pectinata). Aquac. Res. 41: e703-e705.

Li ZB (2006). The genetic diversity and differentiation of $H$. ovina populations by allozyme analysis. In: 13th International Congress on Genes, Gene Families and Isozymes (Xiong XG, Yan ZZ and Liang WY, eds.). ICGGFI, Medimond, 201-207.

Ren J and Yang G (2005). Current status of study on pen shell Atrina pectinata and its prospects of application and exploitation. Mar. Fish. Res. 26: 84-88.

Suck An H, Kim BH, Lee JW, et al. (2011). Comparison between wild and hatchery populations of Korean pen shell (Atrina pectinata) using microsatellite DNA markers. Int. J. Mol. Sci. 12: 6024-6039.

Van Oosterhout C, Hutchinson WF and Shipley P (2004). MICRO-CHECKER: software for identifying and correcting genotyping errors in microsatellite data. Mol. Ecol. Notes 4: 535-538.

Yeh FC, Yang R, Boyle TJ, Ye Z, et al. (2000). PopGene32, Microsoft Windows-Based freeware for Population Genetic analysis. Version 1.32. Molecular Biology and Biotechnology Centre, University of Alberta, Edmonton.

Zane L, Bargelloni L and Patarnello T (2002). Strategies for microsatellite isolation: a review. Mol. Ecol. 11: 1-16. 